not all Hox genes are closely linked; François Jacob and Jacques Monod discovered the operon in Escherichia coli, not Lactobacillus; and so on. Popularizers of science have an obligation to get their facts right, and the quality of this book is impaired by the failure to do so.

Brian Charlesworth is at the Institute for Cell, Animal and Population Biology, University of Edinburgh, Edinburgh EH93JT, UK.

\section{(… Corruption and its consequences}

\section{Captive State: The Corporate Takeover of Britain \\ by George Monbiot}

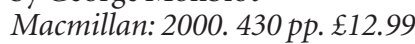

\section{Frances Cairncross}

Whatever you think of George Monbiot's political views, he writes like an angel. Whether on the Isle of Skye, observing Robbie the Pict "with a broad ginger beard and hands like shovels", or walking along the River Usk, where "an old fisherman, gaunt as a heron, stalked up the bank", his book is full of poetic little pictures. Most of them describe the ordinary people who are the victims of the collusion between government and business that he so deplores.

As one of Britain's best campaigning authors and environmentalists, Monbiot has used his powerful pen mainly against the corruption of foreign governments in such sinister parts of the world as the Amazon, Kenya and Indonesia. Now he is describing what he sees as corruption in Britain: the insidious links between government and business which, he believes, is corrupting the political process, capturing politicians and undermining democracy. Corporations, he seethes, "are seizing powers previously invested in government and using them to distort public life to suit their own ends".

In a powerful paragraph, he announces: "The struggle between people and corporations will be the defining battle of the twentyfirst century. If the corporations win, liberal democracy will come to an end. The great social democratic institutions ... will be toppled." Scary stuff, and very much in the mood of the 1999 demonstrations against the World Trade Organization in Seattle.

Yet many of the examples in Monbiot's book are testimony, not to the wickedness of big companies, but to the abysmal ineptitude of bureaucrats and the cynicism of politicians. Take his extremely readable chapter on the scandal of the Skye Bridge. The bridge, which links mainland Scotland with the Isle of Skye, was built largely with private money in exchange for the right to levy a ludicrously high toll, not just on tourists, but also on the

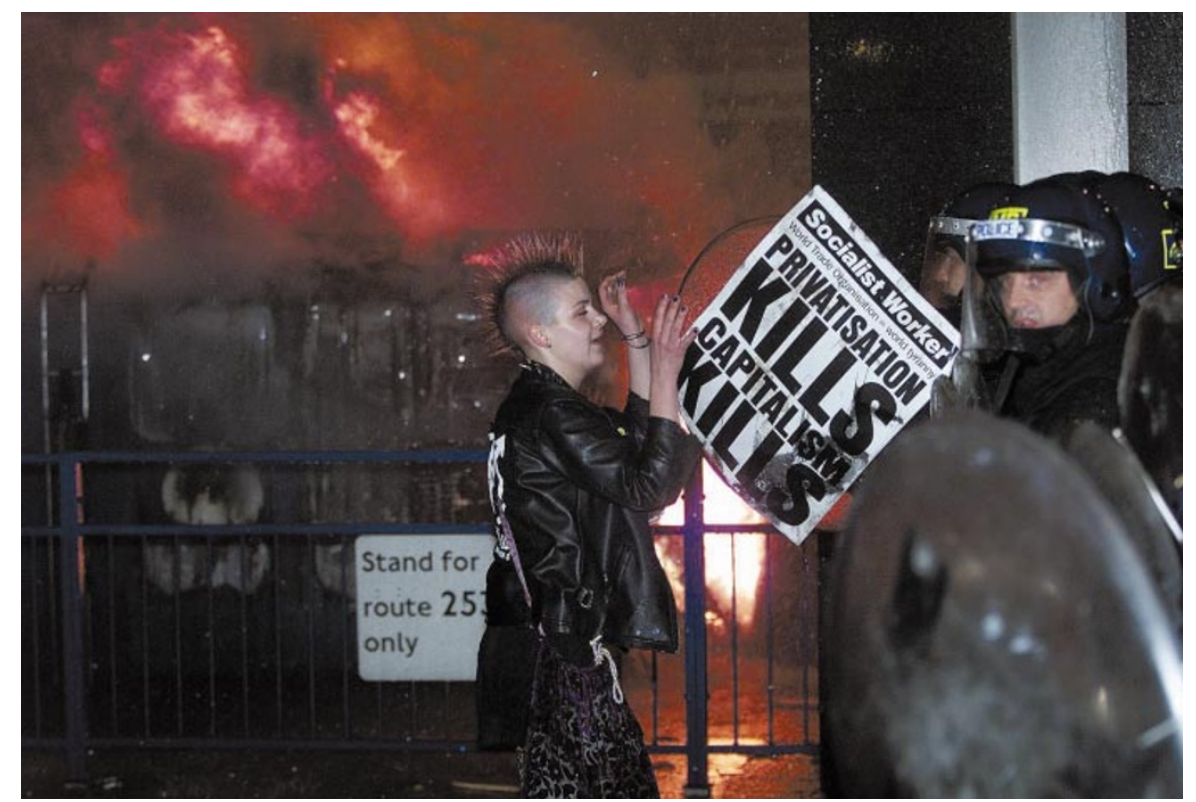

Whenever government touches companies, there is an opportunity for pressure — and corruption.

unfortunate inhabitants of the island.

The villains here are not the Bank of America, which apparently owns the company (although it could do with some public-relations advice here), but the public servants who signed the initial deal and the politicians who, having savaged it while in opposition, then lamely backed down when in power.

Sometimes, the villains are even closer to home. One of Monbiot's pet hates is the outof-town superstore. He chronicles the way supermarket companies extract planning permission by bribing local councils with promises of building new homes or sports centres. Monbiot is eloquent about the misery that big stores inflict on farmers and small shops. Yet is this really about corruption? Surely, the real problem is that people desert their local shops and drive out of town because of the range of products and low prices the superstores can offer. If they were willing to pay a little more and accept less choice, it would be the superstores, not the local butcher and baker, that would go out of business.

So is there no case to answer? On the contrary; wherever government touches companies - where it can grant or withhold permission, pay a subsidy, allocate a contract there is an opportunity for pressure, profit - and corruption. Each transaction puts temptation in somebody's way. The solution, clearly, is to reduce such contacts. But no politician thinks quite that way. After all, the opportunities to grant or withhold favours are an aspect of power and privilege that makes politics worthwhile. But two such contacts feature so often in Monbiot's pages that they surely call for drastic reform.

One is the UK Private Finance Initiative. Not only is this at the heart of the Skye Bridge debacle; it leads to bad decisions on the building of houses, hospitals and roads. In essence, it is an elaborate way for the public sector to get around its own borrowing controls, by getting private companies to do the financing. But, as with all subterfuges, there is a price to be paid, in terms of cost and complexity. Monbiot says the Private Finance Initiative should be scrapped. He is right.

The second corrupting contact is the granting of planning permission. Monbiot's pages are full of stories of large companies that sway local politicians to override their voters' protests. He wants to allow objectors the right to appeal against developers, as developers can appeal against successful objectors. He's right again - although a better reform might be to simplify the process - by setting out a few universal rules on height, density and so on - that could not be overridden for particular projects. The more open a process is to political intervention, the greater the scope for abuse.

For most senior managers of large companies, running a business is not about trying to subvert democracy. Many chief executives would argue that government is not too weak but too powerful - too able to intervene and arbitrarily change the rules. Indeed, the pressures on companies to do deals with government rarely come from a desire to topple democracy or infiltrate government. Most large public companies simply want to stay in business, make money and, above all, sell things to their customers. Their customers - which frequently means you and me - are the true power behind the evil empire. If we don't buy, companies don't sell. In a democracy, the vote is a powerful weapon, but the power of the purse is greater still.

Frances Cairncross is at The Economist,

25 St James Street, London SW1A 1 HG, UK. 